\title{
Structured Financial Products as the Instrument of Financial Credit Assurance for the Companies Involved into Foreign Economic Activities
}

\author{
Ajupov A.A. ${ }^{a}$ \\ Ponomareva I.V. ${ }^{\mathrm{b}}$ \\ a b Kazan Federal University, Institute of Management, Economics and Finance, Kazan, 420008, Russia \\ Email: bashila@rambler.ru
}

\section{Doi:10.5901/mjss.2015.v6n1s3p117}

\begin{abstract}
Indefiniteness in financial markets motivates many market participants to use with increasing frequency the structured financial products. In the research paper at the level of concept we propose the structured financial products aimed at solution of pressing tasks faced by the companies involved into foreign economic activities.
\end{abstract}

Keywords: financial engineering, foreign economic activity, structured financial product, risk engineering

\section{Introduction}

The world financial market, as well as the Russian one however, for the recent 10 years has been subjected to considerable repeated changes on the strength of financial crises, major companies' defaults, economic system instability, etc. As of today, each economic entity of the financial market performing its activities uses traditional financial instruments and their various combinations. It, in its turn, implies new risks and the wish of financial market participants to hedge them by use of the financial instruments. However, upon incurrence of new risk situations, the available financial instruments cannot secure the investments in full, i.e. they do not meet the requirements of the set target.

In the paper we study the materials to find out and form the mechanisms to support the companies involved into the foreign economic activities.

\section{Theory}

Within the frames of the research we come to necessity to create a new financial product; its designing may follow the two variants. First of all, it is taking into account the new encountered circumstances and the available instruments. Secondly, to develop an essentially new financial product by means of financial engineering, at that, having solved the targeted objectives. If to take into account the fact that such a product is going to be aimed at hedging various risks, then there will be used the tools of risk engineering.

Risk engineering stands for the complex of measures including projecting, development and realization of innovative financial products and processes, and also creative research on new products to solve the problems related to management and decrease of the risks faced by financial market entities.

Owing to risk engineering, the innovative financial products appear generated as a result of particular relationship between economic entities in the process of their activities in newly existing conditions of the financial market allowing to meet the requirements related to management and distribution of risks, taxation optimization, investments attraction and gaining the investment income. Besides, such a product is going to provide the final financial results with liquidity, safety and improvement.

Taking the decision on efficient functioning in the conditions of present-day Russian economy by means of using an innovative financial product, the economic entity should thoroughly study the particular situation requiring deep system-factorial analysis, riskiness level, profitability, estimation of financial flow defining the strategy of the organization. Due to significant work content to provide with analysis of the incoming information and necessity to have considerable knowledge, it arises the requirement in getting knowledgeable assistance. It is possible to get such assistance form the investment banks by virtue of the fact that they represent the driving force for the process of creating new financial products. 


\section{Theory}

Consequently, the structured financial products have appeared as a result of search for the solution to the objective to protect from risks the operations with currency, loans, securities and active innovative activities of investment banks in the markets of securities, product, foreign-exchange, credit and other financial markets.

The structured financial product represents a complex financial product which assumes the combination of available financial instruments and complies with the requirements of investors on managing and regulating the risks and as well facilitates the realization of innovative reforms in financial markets.

Realization of the structured financial products is performed via particular mechanism of interrelation between the participants of various financial markets and it becomes a financial service which possesses its user value and is capable of causing demand and supply. In other words, the structured financial product can be sold as a service embodying into particular models of interrelation between the participants of various financial markets by means of exchanging financial instruments, certificates of indebtedness, risks and monetary means, etc. with each other. Let us consider the situations of using the structured financial product as a model in practice.

\section{Results}

Let us assume that one of Russian companies has taken a decision to extend the scope of market for its product, thereby, to enter an export market and to become a participant of international trade. Having signed a deal with a foreign company, the Russian company can face a risk of non-payment or settlement delay for the delivered product from the part of the foreign acquirer which will cause the seller's debts receivables. It can be contributed with various events happening in the country or in the world community which can be referred to political risks.

One more problem related to the subject, the overdue accounts receivable of commercial and non-commercial enterprises involved into foreign economic activities vividly demonstrates the limitations of the settlement system, the same is true about the present-day Russian economy. The definite approach to solve this situation does not exist.

The models specified below should provide all the participants with guarantees and should be quite attractive to the investors. Having studied the theoretical aspects and practical use of depository receipts, we propose the scheme of interrelation for the financial sector, private capital and international financial institutions; while the realization of the scheme, the capital of foreign investors is going to be located in the sector not directly but via the financial instrument of equities market.

Let's consider the model of issuance and circulation of the depositary receipts for the bills of exchange in exportimport transactions (Figure 1).

As seen from Figure 1, the model of issuance and circulation of the depositary receipts for the bills of exchange in export-import transactions contains 8 stages and consists in the following:

1. Let us assume that one of Russian organizations has closed a deal with a foreign company. Then the Russian organization can face risks of non-payment or delay of settlements for the delivered product from the part $3 a$ foreign acquirer which will cause the seller's accounts receivable forthcoming. In order to secure oneself in such a situation, the Russian company can require the issuance of the bill of exchange to the amount of indebtedness.

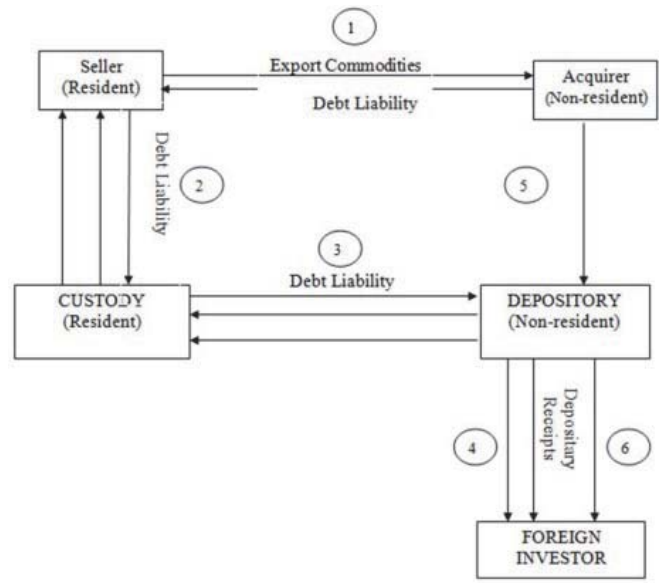

Fig. 1. The model of issuance and circulation of the depositary receipts for bills of exchange in export-import transactions 
2. It exists the risk of bills of exchange forgery due to their issuance in paper that is why the seller deposits the bills of exchange into the custody for further undersigning the custody agreement and issuance of depository receipts for the bills of exchange. In the custody agreement, it takes place the fixation of all the terms and conditions for the issuance of depository receipts as well as the liabilities for each party of the agreement.

3. The custody fulfills its obligations by virtue of the agreement with the depository issuing the depository receipts. The bills of exchange to keep at custody are to be stood in the register in the name of the bailee, whereupon, it is sent a message to depository to the effect that the securities have been immobilized; the custody also provides with the instructions on issuance of the depository receipts.

4. Upon getting all the required information from the custody, the depository proceeds to the issuance of depository receipts for the bills of exchange and to search for a potential investor. Having found the investor, the depository bank submits to it the depository receipts for the bills of exchange in return of monetary assets $\left(S^{\prime}\right)$, which are delivered to the seller in chain via depository and custody.

5. Upon some time having passed, the acquirer is to discharge the bills of exchange paying to the depository a particular amount of money $(S)$ which will subsequently be retransferred to the seller and the investor.

6. After the seller's transfer of the monetary assets to the bank, the bank pays to holder of the depository receipts for the bills of exchange the required amount $\left(S\left(S^{\prime}\right)\right)$, as well as the remaining sum $\left(S^{\prime \prime}\right)$ to the seller via the custody.

However, in present-day conditions the market situation is characterized with instability and it can cause the necessity to attract monetary funds to keep providing with the enterprise successful foreign economic activities. Therefore, we propose the model with the use of escrow account oriented to export-import transactions financing. As far as the use of escrow account in the Russian banking area will allow the creditors to control and manage the loan debtor's flows of money while its realizing the various obligations within the frames of the loan agreement.

Let us review the mechanism of escrow account functioning for the loan transactions aimed at export-import operations financing. (Figure 2).

At making a long-term loan agreement, it is agreed upon the amount of provided loan, total period of the loan, loan payout time, loan payout amount, etc. The peculiarity of the agreement is going to be the status of creditor at exportimport transactions since the lending agency may be whether the resident or non-resident of the borrower's country.

The escrow account opened at the escrow agent's is a service bank account aimed at accumulating on it the monetary assets arriving from the loan debtor's export-import contracts. Liens on the assets credited to the account are to be transferred to the creditors, and at the expense of these receipts the loan and the accrued interest as well as the agent's commission are reimbursed.

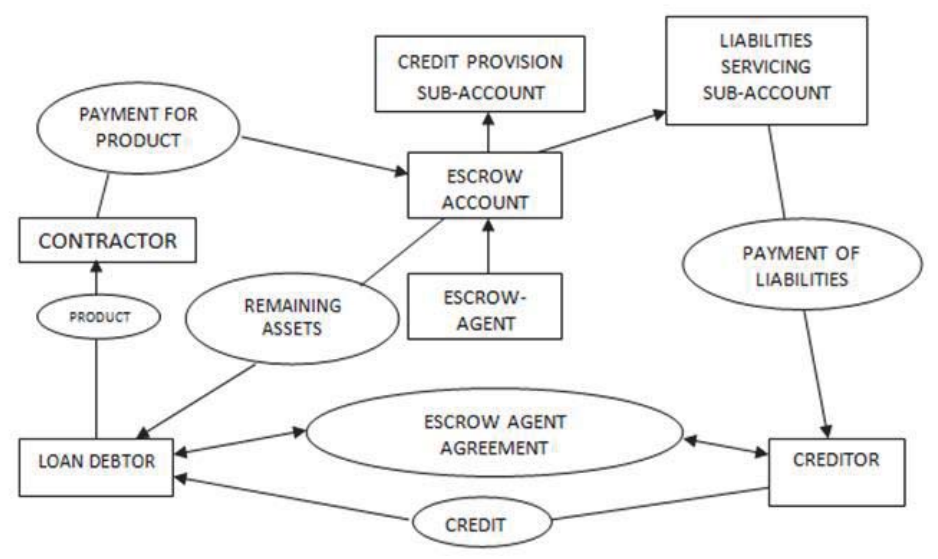

Fig. 2. The model of the escrow account functioning for the credit transactions referred to export-import transactions financing

The escrow account, on which it arrives the payment under the loan debtor's export-import contracts, possesses two more sub-accounts. One of them is dedicated to servicing the liabilities; the second sub-account is for the loan reserve. After the receipts of payment under the contracts, the monetary assets from the assigned account are retransferred on these sub-accounts in the confirmed amount. The remaining assets are transferred on the loan debtor account. All the 
transactions to perform with the sub-accounts are to be done in compliance with the schedule specified in the escrow agent agreement.

The assets in liabilities service sub-account are transferred for paying the commission to the escrow agent, the loan discharge and payment of the interest under this credit in compliance with the loan agreement schedule of payments.

The loan reserve sub-account is used in the cases when in liabilities service sub-account the assets are not sufficient for processing the above mentioned settlements.

At the beginning of each settlement period, the escrow agent calculates the values to credit both sub-accounts. The first transfer is effected on liabilities service sub-account, and then they transfer the assets on the loan reserve subaccount. When the value in the latter account runs up to some particular limit, the remaining assets available in escrow account are transferred on the loan debtor account before the following settlement period start.

Consequently, at the end of work day after the redistribution of assets on the sub-accounts, the escrow account is to have zero balance; the same is also applicable to the liabilities service sub-account.

If the loan debtor's contractors effect payment according to the export-import contracts, then there will be no necessity for the loan reserve sub-account. In case when in liabilities service sub-account there is not sufficient assets to get out of the red and if the loan debtor's contractors do not comply with their obligations in good faith, then from the loan reserve sub-account they will transfer the shortfall amount in liabilities service sub-account. For an obvious reason, the loan reserve sub-account cannot have overdraft.

If dated last but the one settlement for the credit in the loan reserve sub-account it is available the amount equal to the last payment, then the escrow agent will effect it at the expense of these assets. When the liabilities to the creditor are performed in full volume, the escrow account balance will be transferred to the loan debtor; as well as both the assigned account and its sub-accounts will by closed.

At closing the escrow account, the escrow agent sends out to all the participants of escrow agent agreement the letters of advice on its closure and acceptance of possible counter-arguments from the parties within the specified time. If the counter-arguments do not come, the account is closed. But if the counter-arguments do come, the escrow agent is obliged to study them and if necessary, to require additional information to take the final decision.

Adjusted export-import agreements are the contracts for the loan debtor manufactured product supply between the loan debtor and its contractors concluded for all the time of the loan on conditions that the settlement for the contract is sufficient for the loan security and settlement.

For an obvious reason, the creditor is entitled to submit its own terms and conditions to the export-import transactions:

- The term of contracts is to be not less than the total term of the loan;

- The contractors undertake to purchase the product totaling not less than the specified amount, whereas the loan-debtor undertakes to produce and deliver the same quantity of the product;

- The prices for the product are to be agreed upon;

- The maturities for the product are not to exceed 30 days;

- Contractors are to transfer the payment for the product on the escrow account.

\section{Conclusions}

In conclusion, it should be noted that the presented models are the structured financial products which contribute to efficient functioning of the organizations involved into the foreign economic activities as well as allow to solve the previously specified objectives: account receivable level decrease, foreign capital attraction, hedging the political risks and risks of non-payment and provision the participants of foreign economic activities with guarantees.

\section{References}

Aupov, A.A., 2007. Design and Realization of Innovative Financial Products. Moscow: NOTA BENE, pp. 110.

Medvedeva, O.E., 2009. Swap Contract as the Tool of Finance Risk Management, Ph.D. thesis, TSU, Togliatti.

Aupov, A.A., 2007. Production Financial Instruments: Teaching Aid. Togliatti: Togliatti State University, pp.55.

Marshall, J.F. and W.K. Bansal, 1998. Financial Engineering: Complete Manual on Financial Innovations. Moscow: INFRA-M, pp: 23.

Mirkin, Y.M., 2002. Russian Securities Market: Influence of Fundamental Factors, Outlook, and Development Policy. Moscow: Alpina Publisher, pp.52

Aupov, A.A., 2007. Risk engineering as element of financial engineering in the market of innovative financial products. Economic 
Sciences, 12 (37): pp. 363-369.

Kramin, M. V., Safiullin, L. N., Kramin, T. V., \& Timiryasova, A. V. (2014). Drivers of economic growth and investment attractiveness of Russian regions. Life Science Journal, 11(6s).

Kramin, T. V., Ismagilova, G. N., \& Kramin, M. V. (2014). Assessment of Effect of Large Investment Projects on Development of Investment Potential of Regions of Russia as Exemplified by Universiade 2013 in Kazan1. Mediterranean Journal of Social Sciences, 5(18), 255.

Kramin, T. V., Safiullin, L. N., \& Timiryasova, A. V. (2014). Defining Priorities of Management of Investment Attractiveness of the Region and their Consideration in the Framework of Implementing Large Sports Events1. Mediterranean Journal of Social Sciences, 5(18), 275.

Galochkin, M.I., 2014. Securities market regulation in the conditions of stagnation. Vector of Science of Togliatti State University, 1 (27), pp. 93-96.

Schneider, O.V., V.V. Schneider and E.G. Loktionov, 2009. Interrelation of investment attractiveness and financial status from the standpoint of organization development perspective. Vector of Science of Togliatti State University, 7 (10): pp. 229-233.

Medvedeva, O.E., 2011. The use of derivatives in real sector of economy. Herald of Samara State University of Railroads, 2, pp. 17-24.

Ponomareva, I.V., 2014. The Influence of Political Risks on Foreign Economic Activities of Russia. Baltic Humanitarian Journal, 2, pp. 73-76. 